Institute of $\mathbf{F}_{\text {ood and }} \mathbf{A}_{\text {gricultural }} \mathbf{S}_{\text {ciences }}$

\title{
Cultural Guidelines for Commercial Production of Interiorscape Dieffenbachia 1
}

Jianjun Chen, Dennis B. McConnell, Richard J. Henny, and Kelly C. Everitt ${ }^{2}$

Dieffenbachia is a monocot of the Araceae family native to the Caribbean, Central America, and South America with about 30 species and over 100 cultivars. It is a popular choice among interiorscapers due to its low light tolerance, easy production, and attractive foliar variegation. Some of its common names include Dumb Cane, Leopard Lily, Galatea, Mother-in-law Plant, and Yalu Ni Vavalagi. This article describes common species and cultivars in the foliage plant industry (see Table 1), provides guidelines for their culture and interior use, and lists physiological problems that may be encountered during production and interiorscape use (see Table 3 ).

Although popular for their ornamental values, Dieffenbachia plants should be handled with great caution because all parts of the plant contain calcium oxalate crystals, proteolytic enzymes, and certain compounds that can cause inflammation on contact. Ingestion of Dieffenbachia causes irritation of the lips, mouth, throat, and tongue, hence the common name, Dumb Cane. Contact with the plant sap can also irritate the skin. Thus, wearing gloves and other protective covering is suggested when handling this plant. Additionally, it is best to prevent children and pets from physical contact with Dieffenbachia.

\section{Cultural Guidelines}

\section{Propagation}

Dieffenbachia can be propagated by seed, tip or cane cuttings, division, and tissue culture. Seed is not commonly used except in breeding. Rooting is performed in media containing $50 \%$ peat, $25 \%$ bark, and $25 \%$ perlite by volume with $\mathrm{pH} 5$ to 6 and soluble salts readings of 1 to $2 \mathrm{dS} / \mathrm{m}$. Roots will form in 3 to 8 weeks if a minimum media temperature of $75^{\circ} \mathrm{F}$ and proper media moisture are maintained. Most Dieffenbachia species are now propagated by tissue culture because viruses and pathogens can be eliminated through this method.

\section{Production}

Rooted cuttings or tissue cultured liners can be planted in 6-inch, 8-inch, or 10-inch pots, depending on cultivar, using commercial media that are formulated with peat, pine bark, vermiculate, or perlite. Media $\mathrm{pH}$ should be 6.0 to 6.5 and soluble salts levels of 1 to $2 \mathrm{dS} / \mathrm{m}$. Plants should be grown in greenhouses under $80 \%$ shade (2,500 foot candles), relative humidity of 60 to $100 \%$, and temperatures

1. This document is ENH880, one of a series of the Environmental Horticulture Department, Institute of Food and Agricultural Sciences, University of Florida. First published: March 2003. Please visit the EDIS web site at http://edis.ifas.ufl.edu.

2. Jianjun Chen, Assistant Professor, Mid-Florida Research and Education Center and Environmental Horticultural Department, Dennis B. McConnell, Professor, Environmental Horticultural Department, Richard J. Henny, Professor, Mid-Florida Research and Education Center and Environmental Horticultural Department, and Kelly C. Everitt, Research Assistant, Mid-Florida Research and Education Center at the Institute of Food and Agricultural Sciences, University of Florida.

The Institute of Food and Agricultural Sciences is an equal opportunity/affirmative action employer authorized to provide research, educational information and other services only to individuals and institutions that function without regard to race, color, sex, age, handicap, or national origin. For information on obtaining other extension publications, contact your county Cooperative Extension Service office. Florida Cooperative Extension Service/Institute of Food and Agricultural Sciences/University of Florida/Christine Taylor Waddill, Dean. 
between 60 and $90^{\circ} \mathrm{F}$. If plants are fertigated via a drip or ebb-and-flow irrigation, water-soluble fertilizers with $\mathrm{N}-\mathrm{P}_{2} \mathrm{O}_{5}-\mathrm{K}_{2} \mathrm{O}$ at 3-1-2 ratio, such as a 24-8-16 or 18-6-12 with micronutrients, can be dissolved in irrigation water to obtain a solution with $\mathrm{N}$ at a concentration of $200 \mathrm{ppm}$. Depending on production temperatures, plants can be fertigated once or twice a week using the solution. If controlled-release fertilizers with $\mathrm{N}-\mathrm{P}_{2} \mathrm{O}_{5}-\mathrm{K}_{2} \mathrm{O}$ ratios of 3-1-2 are used, apply $24 \mathrm{lb} \mathrm{N}$ per 1,000 square feet annually. Potting media should be kept moist but not wet when controlled-release fertilizers are used in production. Growers are strongly recommended to monitor the nutrient status of potting media by checking soluble salts levels biweekly using an electrical conductivity (EC) meter. Media solution can easily be extracted by the pour-through method. If EC readings fall below $1.0 \mathrm{dS} / \mathrm{m}$, additional fertilization is needed; whereas if EC readings are above $3.0 \mathrm{dS} / \mathrm{m}$, growers should reduce either the frequency or amount of fertilizer applications. It is also recommended to stop fertilizing one month before shipment. Table 2 provides a general guide for determining if Dieffenbachia is appropriately fertilized based on leaf analysis.

\section{Shipping and Interior Care}

During shipping, maintain a temperature range of 60 to $65^{\circ} \mathrm{F}$. If the temperature drops below $55^{\circ} \mathrm{F}$, chilling injury may occur. Dieffenbachia leaves are fragile, so a sleeve is needed. Handle the plants with gloves to prevent irritation from the sap.

Dieffenbachia species have been used in interiorscapes for over 100 years but maintaining its aesthetic appearance indoors is a challenge. Plants may lose foliar variegation and become tall and leggy. Also, leaf edges may dry and turn brown or the lower leaves may die. The secrets to interior success are as follows. (1) Select the right cultivars for the interior light levels. For example, 'Star Bright' and 'Snow Flake' will tolerate low light levels of 50 foot candles, whereas 'Camille' requires of 150-250 foot candles to remain attractive. Inappropriate low light levels cause foliar variegation reduction and excess stem elongation. (2) Reduce or cease fertilizing. If soluble salts are $1.0 \mathrm{dS} / \mathrm{m}$ or above when solution is extracted by the pour-through method, do not fertilize; if soluble salt levels are higher than 2.0 $\mathrm{dS} / \mathrm{m}$, leach the media with water to reduce potential leaf burning. Usually, plants do not need fertilizer for at least two months after purchase. Afterward, water with a solution containing $\mathrm{N}$ at $100 \mathrm{ppm}$ made from a water-soluble fertilizer mentioned above once a month. (3) Maintain a temperature range of 70 to $85^{\circ} \mathrm{F}$ and avoid drafts. (4) Do not expose plants to direct sun or excessive brightness, which may give leaves a washed-out appearance. (5) Keep media moist but not wet.

Remove lower leaves as they eventually drop. If the foliage becomes too sparse, trimming it back to a 6-inch height can revitalize it. Wipe the leaves from time to time with a damp cloth to remove dust. Repot the plant as needed. 
Table 1. A listing of common cultivars available in Florida as of 2002.

\begin{tabular}{|c|c|c|}
\hline Species or Hybrid & Cultivar & Characteristics \\
\hline \multirow[t]{3}{*}{ D. amoena } & 'Tropic Alix' & $\begin{array}{l}\text { A compact and dense plant with large leaves. The foliage has white } \\
\text { markings feathering from the midvein. }\end{array}$ \\
\hline & 'Tropic Snow' & $\begin{array}{l}\text { A large-size cultivar. Its leaves have white centers fading into yellow } \\
\text { with a large green border and matching midvein. }\end{array}$ \\
\hline & 'Bryant Compacta' & $\begin{array}{l}\text { Upright and outwardly arching growth habit, full and dense look with } \\
\text { typically } 20 \text { offshoots per plant; distinct green, light green, and white } \\
\text { variegation. }\end{array}$ \\
\hline \multirow[t]{7}{*}{ D. maculata } & 'Perfection' & $\begin{array}{l}\text { Deep green leaves with an extensive and uniform variegation pattern of } \\
\text { cream-white and a compact growth habit. }\end{array}$ \\
\hline & $\begin{array}{l}\text { 'Perfection } \\
\text { Compacta' }\end{array}$ & A sport from 'Perfection' with a dwarf habit and more basal shoots. \\
\hline & 'Marianne' & $\begin{array}{l}\text { A striking sport of 'Perfection' with the entire leaf in a bright golden } \\
\text { yellow color except for the dark green margin. }\end{array}$ \\
\hline & 'Camille' & $\begin{array}{l}\text { A sport from 'Marianne' that has the same multiple basal shoots as } \\
\text { 'Perfection Compacta'. }\end{array}$ \\
\hline & 'Rebecca' & $\begin{array}{l}\text { A sport of 'Camille'; bright yellow-green to near white foliage with } \\
\text { green edges and blotches and a clumping habit with a vigorous, full, } \\
\text { and compact look. }\end{array}$ \\
\hline & 'Compacta' & $\begin{array}{l}\text { Mature foliage is almost speckled with green on a yellow background. } \\
\text { Opposite colors in the juvenile form. }\end{array}$ \\
\hline & 'Carina' & $\begin{array}{l}\text { A sport of 'Camille'. Leaves have a white feather shape over half of } \\
\text { the surface. }\end{array}$ \\
\hline \multirow[t]{9}{*}{ Hybrid } & 'Honey Dew' & $\begin{array}{l}\text { A sport from 'Camille'. The inner panel of leaves is more yellow than } \\
\text { the ivory that is common to 'Camille'. }\end{array}$ \\
\hline & 'Gold Rush' & $\begin{array}{l}\text { The foliage has a white midvein that branches out into the mostly } \\
\text { yellow surface. The margin has a thin stripe of green. }\end{array}$ \\
\hline & 'Parachute' & $\begin{array}{l}\text { A sport selected from the hybrid 'Paradise'. The color pattern is akin to } \\
\text { leopard spots of green on yellow. }\end{array}$ \\
\hline & 'Sparkles' & $\begin{array}{l}\text { The deep-yellowed leaves are outlined in green and splotched } \\
\text { randomly around a white midvein. }\end{array}$ \\
\hline & 'Sterling' & The dark green leaves have a simple white branching midvein. \\
\hline & 'Tropic Marianne' & The majority of the leaf is solid yellow with a thin margin of green. \\
\hline & 'Tropic Honey' & $\begin{array}{l}\text { Similar to 'Tropic Marianne' but its showy yellow-green leaf color is } \\
\text { highlighted by a bright white midrib and dark green margins. Well } \\
\text { branched and compact with short petioles. }\end{array}$ \\
\hline & 'Tiki' & $\begin{array}{l}\text { A sport selected from Dieffenbachia x Memoria-corsii. Narrow and } \\
\text { wavy leaves that have green and gray variegation with white spotting. }\end{array}$ \\
\hline & 'Snow Flake' & $\begin{array}{l}\text { A selection from 'Tiki'. The foliage is almost entirely white and gray } \\
\text { with very little green. }\end{array}$ \\
\hline
\end{tabular}


Table 2. Nutrient concentrations in leaves that are generally considered low, medium, or high for Dieffenbachia growth.

\begin{tabular}{||l|l|l|l||}
\hline \hline Nutrient & Low & Medium & High \\
\hline Nitrogen (\%) & $<3.0$ & $3.0-5.0$ & $>5.0$ \\
\hline Phosphorus (\%) & $<0.2$ & $0.2-0.8$ & $>0.8$ \\
\hline Potassium (\%) & $<2.0$ & $2.0-5.0$ & $>5.0$ \\
\hline Calcium (\%) & $<1.0$ & $1.0-2.5$ & $>2.5$ \\
\hline Magnesium (\%) & $<0.3$ & $0.3-1.0$ & $>1.0$ \\
\hline Sulfur (\%) & $<0.2$ & $0.2-0.5$ & $>0.5$ \\
\hline Iron (ppm) & $<50$ & $50-300$ & $>300$ \\
\hline Manganese (ppm) & $<30$ & $30-200$ & $>200$ \\
\hline Zinc (ppm) & $<15$ & $15-200$ & $>200$ \\
\hline Copper (ppm) & $<5$ & $5-40$ & $>40$ \\
\hline Boron (ppm) & $<15$ & $15-40$ & $>40$ \\
\hline \hline
\end{tabular}

Table 3. Causes and effects of various physiological problems.

\begin{tabular}{||l|l|l||}
\hline \hline Symptoms & Probable Cause & Treatment \\
\hline $\begin{array}{l}\text { Overall veinal chlorosis in the } \\
\text { newer foliage. }\end{array}$ & Iron deficiency & A drench or spray with chelated iron. \\
\hline $\begin{array}{l}\text { Interveinal yellowing or } \\
\text { chlorosis around the margin } \\
\text { of old leaves. }\end{array}$ & Magnesium deficiency & $\begin{array}{l}\text { Spray with magnesium sulfate (Epsom salts) or chelated } \\
\text { magnesium. A drench with magnesium sulfate also } \\
\text { helps. }\end{array}$ \\
\hline $\begin{array}{l}\text { Leaves are small and } \\
\text { downward curved with } \\
\text { necrotic edges. Severe root } \\
\text { loss can also occur. }\end{array}$ & $\begin{array}{l}\text { Excess media moisture } \\
\text { and soluble salts }\end{array}$ & $\begin{array}{l}\text { Leach the media to remove the excess soluble salts. Stop } \\
\text { fertilizing to reduce soluble salt levels. Reduce irrigation } \\
\text { frequency if rooting medium stays too wet. }\end{array}$ \\
\hline $\begin{array}{l}\text { Young leaves have a watery } \\
\text { and transparent appearance } \\
\text { usually in the winter. }\end{array}$ & Water-soaked foliage & $\begin{array}{l}\text { This problem is usually temporary, developing when plants } \\
\text { are grown in high air temperatures and relatively low soil } \\
\text { temperatures. Increasing soil temperature or reducing air } \\
\text { temperature will alleviate the situation. }\end{array}$ \\
\hline $\begin{array}{l}\text { The lower leaves are yellow. } \\
\text { foliar chlorosis }\end{array}$ & $\begin{array}{l}\text { Fellow leaves are often the result of excess moisture loss. } \\
\text { Increase the humidity to control this problem. }\end{array}$ \\
\hline \hline
\end{tabular}


Table 3. Causes and effects of various physiological problems.

\begin{tabular}{||l|l|l||}
\hline \hline Symptoms & Probable Cause & Treatment \\
\hline $\begin{array}{l}\text { Areas between main veins } \\
\text { become chlorotic or light } \\
\text { brown. }\end{array}$ & $\begin{array}{l}\text { Cold temperature } \\
\text { damage }\end{array}$ & $\begin{array}{l}\text { Prevent exposure to low temperatures. Avoid extreme or } \\
\text { abrupt changes in temperature. }\end{array}$ \\
\hline $\begin{array}{l}\text { A small notch appears, } \\
\text { usually on the lower edge of } \\
\text { the leaf. }\end{array}$ & Leaf notching & $\begin{array}{l}\text { The exact cause is unknown, but notching seems to occur } \\
\text { when plants have been exposed to stress conditions such } \\
\text { as drought, high temperatures, or improper pesticide } \\
\text { application. Review cultural practices and environmental } \\
\text { conditions. Modify as needed. }\end{array}$ \\
\hline \hline
\end{tabular}

